\title{
Anxiety as Predictor of Aspiration among the Achievers
}

\author{
* Syeda Farhana Kazmi ${ }^{1}$, Shabbir Ahmed Rana ${ }^{2}$, Sher Dil ${ }^{3}$ \& Shaista Iqbal ${ }^{4}$ \\ 1. Assistant Professor, Department of Psychology, Hazara University, Mansehra Pakistan \\ 2. Associate Professor, Department of Applied Psychology, Government M.A.O College, Lahore, Pakistan \\ 3. Lecturer, Department of Psychology, Hazara University, Manserha Pakistan. \\ 4. Teaching Assistant, Department of Psychology, Hazara University, Manserha Pakistan.
}

\begin{abstract}
The present research aimed at to measure the relationship between anxiety and aspiration among academic achievers. A purposive sample consisted of 200 students with average age 15 years of both gender; 100 female students (high academic achievers $=50$, low achievers $=50$ ) and 100 male students ( high academic achievers $=50$, low academic achievers $=50$ ) were taken from Higher secondary schools of Abbottabad. Taylor manifest anxiety scale (Taylor \& Spence,1953) along with Study-Habit Scale( Ansari,1983) were administered on the sample. Results showed satisfactory reliability that is .747 and .836 for the both scales respectively. Analysis of results revealed that the pattern of achievement of a student depends on his/her aspiration level and anxiety has association with level of aspiration in students. Study further highlighted that achievers tend to have considerably higher achievement scores have higher aspiration as the result of perceived high anxiety. Students with low achievement scores have lower aspiration as the result of perceived high anxiety. Least-square line of Regression with achievement status as the outcome of aspiration and anxiety as the predictor variable indicated good model of fit showed that results indicate there was positive significant relationship between students' high level of academic achievement and anxiety. The study filled some identified gapes in literature and tries to stress the need for more research on this topic.
\end{abstract}

Key words: Anxiety, Aspiration, low achievers and high achievers

\section{Introduction}

Examination stress and test anxiety are pervasive problems in modern society. Every year, millions of students underperform in school and university because of heightened test anxiety, which is set of phenomenological, physiological and behavioral responses that accompany concern about possible negative consequences or failure on an exam or similar evaluative situation (Zeidner, 1998).

Many psychologists are often interested in knowing the factors that cause individual differences in academic performance individually. Anxiety as the achievement of effort is now seen as possible factor that affects a person's academic ability. It varies markedly from one individual to another. Thus, some individuals will be relatively calm when it comes to completing a test, whilst others will generally perceive examinations as more dangerous or threatening and experience more intense levels of state anxiety when taking tests (Spielberger \& Vagg, 1995).

Aspiration of the students is a term used frequently in education. Early research helped us understand the aspirations, as an expression of the will to achieve and improve. Aspirations can be defined as the student's ability to identify and set goals for the future, while breathing in the present to work toward those goals (Quaglia and Cobb, 1996). This view the aspirations of students is the only one that combines the components of this motivation (inspiration) in the future (ambitions).

There is considerable research on the association of the results and academic motivation (cited in Hornery, Craven, Yeung, \& Ali, 2008) for high school students, two important academic results are as follows: aspirations of high grades and the desire for further education, these aspirations are an additional engine that could affect student motivation and academic achievement. According to McInerney, Yeung, and McInerney (2001) a sense of purpose of learning is an important psychological construct that provides two aspects of the effort, namely anxiety and motivation. There is the traditional Chinese students and their parents believe in the traditional thinking of strong associations with the aspirations of work and effort (Tsang, 1992). An aspiration level can be interpreted as a result, it takes a special position in the decision process. Topic of code in the claim level results as the successes and results below the level of aspiration as a failure. It values the overall probability of success and the total probability of failure(Diecidue and Van de Ven, 2008).

Achievement aspiration is believed to be one of the driving forces for the development of a concept or idea and yours is like a virus to spiritual people to be competitive, work hard and causes more resistance. Educational aspirations relating to the early presentation of their own academic abilities and the highest level of education of individuals expected to achieve (Furlong \& Cartmel, 2005). 
Educational aspirations were developed early in a student's academic career and are generally theorized to influence academic achievement is improving the ability to participate in educational opportunities. Students who have high academic aspirations are more likely to take advantage of educational opportunities that can lead to academic success. Also, students with low academic aspirations are less likely to take advantage of these opportunities, thus limiting their future educational opportunities (Arbona, 2000).

Achievement is definitely as a result of emotional conflict between striving for success and avoiding failure (Covington, 2004; Heafner, 2004). If a student does not feel afraid he will not be able to do work harder to achieve the goal (Seligman, 2002). As aspiration for success has been the focus of a large amount of research in studies of personality, has a way to measure work motivation has become a source for researchers to explore their representation in the population (Pigatt, 2009).

The most common technique for high academic achievement is the skills of time management, homework, get help when needed and build a relationship with the teachers, and reading. Time management involves organizing school supplies, self-efficacy, control beliefs, anxiety and aspirations and beliefs that maintain the behavior towards a particular goal (as cited in Creasey, Jarvis \& Knapcik,2009).

Why an individual completes a task, the value component of motivation focuses on the reasons why students become involved (or not involved) in an instructional activity (Pintrich \& DeGroot, 1990). It defines students' beliefs about the importance or value of a task and why students approach or avoid a task (Brophy, 1983). Self-worth theory rests upon the perception that students are motivated to establish, maintain, and promote a positive self-image (Covington, 2000).

Stipek (1997) found that there is a personality dimension that is directly associated with greater success in education, to feel the need for individual achievement. And one of the perennial or in other words, continuous education problem a lack of motivation. The only needs that will be relevant here will be those that the absence of the condition is also motivated by the situation.

Although many studies have been conducted, one conclusive research work is a meta-analysis study conducted by Covington, Omelich, and Schwarzer (1986) results support the anxiety resulting from the disruptive effects of perceptions of reduced capacity, instead of the disturbing influence of diffuse emotional arousal.

Hernandez (1994) examined the best predictors of academic success was the ability to self-concept and educational aspirations. High performance grew in self-concept of ability and learning aspirations in relation to literacy skills. Brown, Robinson, and Kurpius (1997) results suggest that the academic preparation and aspirations, academic performance and interaction with the best difference between faculty and staff students who persisted in school and those who do not.

Mousavi, Haghshenas, and Alishahi (2008) identified the causes of poor school performance included poor grades or down as a result of a yield spread ability, the early repetition lacks school, disinterest in learning, low self-esteem, anxiety, failure to complete school or at home, disruptive behavior and school dropouts.

Bendura, Barbaranelli, Caprara, and Pastorelli (1996) analyzed the children's belief in their efficacy to regulate their own learning and learning outcomes in turn contributed to student success both independently and through the promotion of high educational aspirations and prosocial behavior and reducing vulnerability to feelings of depression.

Heafner and McCoy (2001) study found that feelings of effectiveness and therefore motivation to switch tasks is maximized not only by the amount of success, but manages the difficult tasks optimally. In other words, motivation depend on the best fit between difficulty and skill. It was also found that high self-perceived academic competence was positively correlated with GPA (weighted average, a measure of performance).

Although external motivation was negative predictive of academic success for young Indian immigrants in Canada. There was no significant predictor of academic success of Indian youth in India (Areepattamannil, Freeman, \& Klinger, 2011).

Differences in the anxiety level of education were also related to differences in study habits, and these in turn linked to the GPA. Results recommend the use of specific scales, rather than general anxiety as predictors of academic performance and involve learning habits as a process of mediation can (Otello \& Patricia, 1969).

Culler and Holahan (1980) studied quality of study habits and how much study time positively related to academic performance, while the missing classes and delay test was inversely related to performance. The results are discussed in terms of dominant interference model of test anxiety. McKeachie, Karabenick, Wilbert, and Lin (1998) found the exact relationship between test anxiety and self-regulation in students' motivation and use of learning strategies.

Yeunga and McInerney (2005) studied Grade 7 students were significantly higher in the direction of effort and work and career aspirations that from 9 to graders, and higher scores in praise orientation than 11th students. The apparent decreased motivation may from Grade 7, especially in the direction of work and effort, 
both related to a mastery orientation dimension that was supposed to be a major driving force for excellence, requiring immediate attention students' motivation in college classes in the secondary.

\section{Objective}

- To investigate the relationship between anxiety and aspiration among Pakistani students.

- To find out the level of anxiety among the learners and its relationship with the academic achievement of the students at secondary level.

- It was observed that the pattern of achievement of a learner depends on his/her aspiration level. The study also aims to dig out the relationship between student's aspiration and their academic achievement.

- The study also aims to find out that as higher the level of anxiety is the harbinger of higher aspiration

Hypotheses among studies.

Hypothesis1: There will be positive correlation between anxiety and aspiration among high achiever students. Hypothesis2: There will be negative correlation between anxiety and aspiration among low achiever students. Hypothesis 3: There will be likelihood that students tend to have considerably higher achievement scores have higher aspiration as the result of perceived high anxiety.

Hypothesis 4: There will be likelihood that students tend to have considerably lower achievement scores have lower aspiration as the result of perceived high anxiety.

\section{Operational Definition of the Variables}

The study has following variables:

Anxiety

In the present research anxiety is operationally defined as the score on anxiety scale (Taylor \& Spence,1953).

Aspiration

Aspiration is an expression of the desire to achieve and improve. It's a level of motivation that overcomes task complexity with perpetual efforts and push one's to work toward those goals. Aspiration is operationally defined as scores obtained on study Habit and attitude scale(Ansari, 1983).

\section{Academic Achievement}

Academic achievement is operationally defined as scores obtained by the students in 10th Grade of Higher Secondary School Examination conducted by Federal board.

\section{High achievers}

High achievers are those students receiving "A" grade in 10th class of Secondary School Examination conducted by Federal board. They generally stand in top ten positions in the school and having high aspiration for becoming highly successful.

\section{Low achievers}

Low achievers are those students who obtaining "C" grade in 10th class of Secondary School Examination conducted by Federal board. They generally remain in lower ten positions in the school and having low aspiration for goal achievement with respect to academic accomplishment.

\section{Methodology}

Research Design

Cross-sectional survey design was employed in this study

Sampling Technique

Purposive convenient sampling technique was used.

\section{Sample}

Participants for the study were selected in 2011, 11th grade classes from Higher secondary schools in Abbottabad and Havellian were included in the investigation comprising a sample of $N=200$ students. At the time of the measurement occasion (June 2011), students were on average 15 years old with both gender, 100 female students (high academic achievers with Grade A =50, low academic achievers with Grade $\mathrm{C}=50$ ) and 100 male students ( high academic achievers with Grade $\mathrm{A}=50$, low academic achievers with Grade $\mathrm{C}=$ 50).The list of high achievers and low achievers was got from the clerical staff of principal of the respective schools.

\section{Research Tools}

1. Taylor manifest anxiety scale: This scale contains 50 items and response category is dichotomous consisting of true and false. Code of 1 is assigned to true and 2 is assigned to false. Higher scores indicate high level of anxiety.

2. Study-Habit Scale: Another instrument was" Study-Habit Scale" developed by Ansari (1983) for measuring the student's aspiration level such as completion of school assignments, understanding of 
academic concepts and frustration caused by mismanagement of time during the academic session. Questions were posed in different ways to conclude the techniques of high academic achievement. The most common technique for high academic achievement is the skills of time management, homework, get help when needed and build a relationship with the teachers and reading. Time management involves organizing school supplies, making to do lists, prioritizing and planning. There are 31 items with five response options. Five response categories of points used for each statement, such as $5=$ strongly agree, agree $=4$, uncertain $=3$, disagree $=2$, disagree $=1$ for positive valence part while the negative valence items were counted in the reverse order. Results showed satisfactory reliability that is .747 and .836 for the both scales respectively.

Procedure: Intention is to check the anxiety and aspiration level of the students. Taylor manifest anxiety scale and Study-Habit Scale was used to collect data. For data collection respondents were personally approached by the researcher and questionnaire were distributed individually in face to face fashion. Clear instructions were prepared for the respondents. They were requested to go through the general instructions first and then to respond. The respondents were asked to decide about agreement with the statements and mark the relevant response category honestly. The questionnaire was distributed randomly to the subjects with request to complete and return it. The cooperation from institution teachers was remarkable.

\section{Results}

For the purpose of analyzing the result through statistical procedure it was subjected to various kind of analysis. Results of data analysis are in the forms of tables given below.

Table 1

Relationship between Anxiety and Aspiration of high grade students $(N=100)$

$* * * \mathrm{P}<0.001 ; * * \mathrm{P}<0.006$

\begin{tabular}{ccc}
\hline & Anxiety & Aspiration \\
\hline High Achievers & 0.550 & 0.250 \\
\hline $01 ; * \mathrm{P}<0.006$
\end{tabular}

Above table indicates that there is positive significant relationship between students high level of academic achievement and anxiety $(\mathrm{r}=0.550, \mathrm{P}<0.001)$. Students with high achievements also showed significant positive correlation between their academic achievement and motivation at 10th school level $(\mathrm{r}=0.250, \mathrm{P}<$ O.006) and presently studying at $11^{\text {th }}$ level in Higher secondary school.

Table 2

Relationship between Aspiration and Anxiety of low grade students $(N=100)$

\begin{tabular}{|c|c|c|}
\hline & Anxiety & Aspiration \\
\hline Iow Achievers & 0762 & -176 \\
\hline
\end{tabular}

Above table indicates that there was positive significant relationship between students low level of academic achievement and anxiety $(\mathrm{r}=0.762, \mathrm{P}<.001)$. Students with low level of academic achievement (academic grade) showed negative significant correlation between their achievement and motivation level $(\mathrm{r}=-0.176, \mathrm{P}<$ $0.04)$ in (10th grade) and presently studying at $11^{\text {th }}$ level in Higher secondary school.

Table 3

Regression Analysis Anxiety as Predictor of Aspiration among High Achievers $(N=100)$

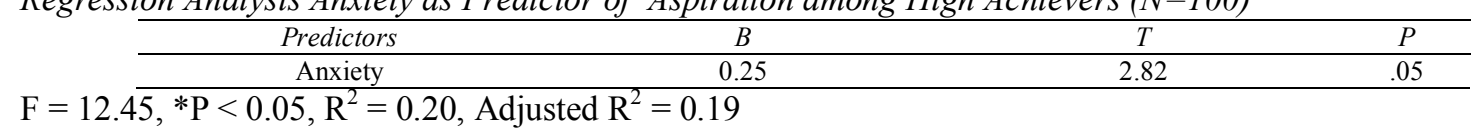

Above table revealed that Regression measures anxiety is predictor of aspiration among the students who obtained grade " $A$ " in (10th grade) and presently studying at $11^{\text {th }}$ level in Higher secondary school. Findings also include the $\beta, \mathrm{t}$, and $\mathrm{p}$ values of the test and significance level is also shown in table. This is satisfactory.

Table 4

Regression Analysis Anxiety as Predictor of Aspiration among Low Achievers $(N=100)$

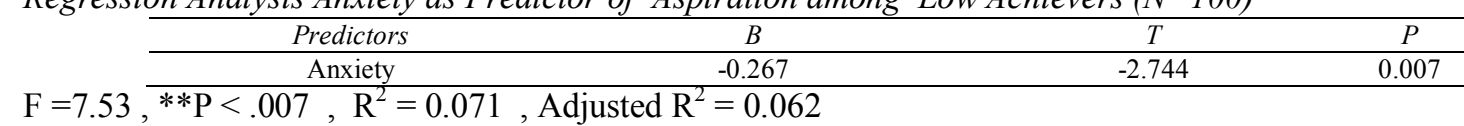

Above table revealed that anxiety is not the significant predictor of aspiration / motivation among low achiever (students who obtained "C" grade in 10th). Table also showed that students' aspiration /motivation decreased as their level of anxiety increased. Regression Analysis Anxiety as a Predictor of Motivation among high 
Achievers Findings also include the $\beta, \mathrm{t}$, and $\mathrm{p}$ values of the test and it indicates that anxiety is not significant predictor of motivation among high academic achievers

\section{Discussion}

This study was conducted to investigate anxiety and aspiration among the students in schools with high and low achievement, although the relationship between anxiety and motivation was based on academic achievement were also examined. The results reveal that students made significant efforts who have obtained A grade in Matric showed a significant positive correlation between their performance and aspiration/motivation in relation to their academic success in school $(\mathrm{r}=0.250, \mathrm{P}<0.006)$ (see Table 1). This finding is also similar to Schunk (1991) suggest that the achievement was related to more comprehensive general motivation and ambition. In connection with this study, previous researchers (e.g., Anis-ul-Haque, 1998 ; Sideridis, 1998) stressed the usefulness of self-efficacy in predicting the outcome of motivation that played a major role in student success.

The aspiration of students is believed to have a significant influence on learning outcomes. Previous researchers (e.g., Jayanti, 2008 ; Urhahne, Chao, Florineth, Luttenberger \& Paechter, 2011) also confirms that educational aspirations may be an important factor in predicting academic success. There is considerable research on the association of the results and academic motivation (McInerney, Roche, McInerney, \& Marsh, 1997; Schunk, 1991; Yeung and McInerney, 2005; Hornery, Craven, Yeung, \& Ali, 2008) for high school students these aspirations are an additional engine that could affect student motivation and academic achievement.

The results of recent research shows that there was positive significant correlation between the level of student achievement and anxiety $(\mathrm{r}=0.550, \mathrm{P}<0.001)$ Table 1. Yousafi, Abu Talib, Mansor, Juhari (2010) also confirmed the same relationship between test anxiety and academic performance among adolescents in Iran respondents from more than 400 students (200 boys and 200 girls), the result shows that there is a significant correlation between test anxiety and academic performance among young students.

In the second analysis the results showed that there is a negative relationship between educational achievement and motivation( $\mathrm{r}=-0.176, \mathrm{P}<0.04)$ with high level of anxiety( $\mathrm{r}=0.762, \mathrm{P}<0.001)$ among the students who have obtained $\mathrm{C}$ grade in Matric(Table 2). Some past studies have more or less obtained the same findings. Mohsen and Mansoor (2009) examines the significant negative correlation between test anxiety and academic performance, after a study of 110 students from the University of Isfahan. The results with regard to educational achievement are also in line with those obtained from other studies (e.g., Mousavi, Haghshenas, \& Alishahi, 2008) all have reached the conclusion that educational achievement and test anxiety level have a reverse ratio. It means that as test anxiety level increases, educational achievement decreases and vice-versa. Present results are consistent with studies of Jayanti (2008) concluded that educational aspirations may be an important factor in predicting academic success. The educational aspirations of indigenous lower freshmen are minority contributes significantly to the problem leads to lower academic performance. This finding is also similar to Eskeles, Fleming and Gottfried (2001) which was examined in a longitudinal study of elementary through high school years found a combination of these two aspects of continuity points of motivation of these was in the beginning of their schooling at special risk.

Results indicate that there was positive significant correlation between the low academic achievement and anxiety $(\mathrm{r}=0.762, \mathrm{P}<0.001)$. The current conclusion is supported by Elliot and McGregor (1999) also found that test anxiety were documented as a mediator of the negative relationship between performance avoidance goals and exam performance. Covington, Omelich \& Schwarzer (2005) suggested that anxiety is not a uniform response to perceived threat, but rather a number of interacting factors, whose relationship with the individual performances alter the development of a test event to the next. The results support anxiety resulting from the understanding that the interfering effects of reduced ability of perceptions, rather than the influence of emotional arousal embarrassing transmissions.

In the third analysis to test hypothesis 3 regression analysis was performed on the students' aspiration for academic achievement in order to evaluate whether the level of anxiety predicts aspiration/motivation that would result in high grade. It was assumed that there will be likelihood that students tend to have considerably higher achievement scores have higher aspiration as the result of perceived high anxiety. Table $3(\mathrm{~F}=12.45, \mathrm{P}<$ $0.05, \mathrm{R}^{2}=0.20$, Adjusted $\left.\mathrm{R}^{2}=0.19\right)$ showed that anxiety is a predictor of aspiration among high achievers (students with " $\mathrm{A}$ " Grade at $10^{\text {th }}$ class). Previously, researchers are investigating the academic success has been the best predictors of educational aspirations in relation to effective and sustained (e.g., Hernandez, 1994; Brown, Robinson, \& Kurpius, 1997). This result is supported by Hodapp (1989), who has done research on a group of 91 (grade 7) students and 134 (corresponding to graduate students), students in elementary school. The results support the concept of anxiety performance relationship as an interdependent system. Piedmont (1988) study indicates that the positive effects of achievement motivation was constant regardless of the situational 
manipulations. But sometimes situations facilitated performance in additive ways a concern had a differential effect on performance depends on levels of achievement motivation. Vesta (1961)also confirmed that educational aspirations of students may affect what they learn in school and their eventual success in academic. Aspiration is assumed to have both energizing and directive effects on performance often may be attributed to learning.

To test the hypothesis 4 regression analysis was performed on the students' aspiration for academic achievement in order to evaluate whether the level of anxiety predicts low aspiration/motivation that would result in low grade. It was assumed that there will be a risk that students tend to have scores of success is dramatically lower than the result of anxiety is considered high. Table $6\left(\mathrm{~F}=7.53, \mathrm{P}<.007, \mathrm{R}^{2}=0.071\right.$, Adjusted $\mathrm{R}^{2}=0.062$ ) showed that anxiety is a insignificant predictor of aspiration among low achievers of high school students who received grade " $\mathrm{C}$ " in $10^{\text {th }}$ class. The current conclusion is similar to the finding of Cochinwala and Ismail (1986) studied the curvilinear relationship between anxiety and academic achievement of 300 Pakistani youths (male and female). In the same context, Vogel and Collins (1989) believe that students suffering from test anxiety of high and low test anxiety will lower academic performance. In the same context, Marjoribanks' (1988) results support the concept of anxiety performance relationship as an interdependent system. Therefore, these students with moderate levels of test anxiety perform better. Bouffard, Vezeau and Bordeleau (1998) suggest that the greater insight and increased motivation can also be created following the acquisition of a differentiated perception of the ability of early adolescence.

To test the hypothesis 5 regression analysis was conducted on the academic achievement of students in order to evaluate the effect of aspiration on academic performance. Table $5(\mathrm{~F}=7.53, \mathrm{P}<0.012, \mathrm{R} 2=0.062$, adjusted $\mathrm{R} 2$ $=0.053)$ reveled that motivation /aspiration is an important predictor of high performance among students who have received (A) Grade (Class 10).

The study is supported by Campbell (2007) who also believed in the theory of motivation system that is a valid indicator of performance. Dweck and Carol (2009) also found that motivational processes affect the formation of a child, transfer and use of knowledge and skills. Nichols, Kotchick, Barry, and Haskins (2009) results showed that the average American male African use of community resources was significantly related to their positive and educational aspiration. Eccles (2004) also agreed that high self-perceived academic competence was positively correlated with GPA (weighted average, a measure of performance). Piedmont (1988) results showed that the positive effects of achievement motivation was constant regardless of the situational manipulations. But sometimes situations facilitated performance in an additive manner. Anxiety had a differential effect on performance depends on levels of achievement motivation. Although Kurita and Zarbatany (1991) agree that motivation is decreased, in their teens, their results suggest that the decline in motivation occurs only up to grade 9 . Empirical data support the hypothesis that negative effects of performance approach orientation may be due to the presence of avoidance motivation. Sideridis (1998) suggest that dichotomizing performance goal orientation is involved in a good understanding of the processes associated with motivation to succeed, and depression. On the other hand low achievement of the students is seen as a personality trait that distinguished students based on their tendency or taking things work well and compete against a standard of excellence (Vigfield \& Eccles, 2002).

Urhahne, Chao, Florineth, Luttenberger, and Paechter (2011) realised that students were satisfied with the low achievement and assumed that students have learning motivation below their overrated classmates.

\section{Conclusion}

Present study was conducted on school students studying at secondary level from science and arts group in different schools of Abbottabad. Anxiety emerged as a significant predictor of motivation/aspiration in high achievers and insignificant predictor in low achievers. The students who had been overloaded anxiety engaged in healthy habits and resultantly greater motivation for studies that brought high scores among the high achievers and vice versa with low achievers. In high academic achievers factor of aspiration was also studied as the skills, strategies and habits of high academic achievement that contributes to the maintenance of " A" grade at Matriculation level.

On the other hand, regression analysis also assured that high level of anxiety reduces students' educational aspiration such as time mismanagement, incomplete homework, least bother to get help when needed and build a relationship with the teachers and planning for reading. Such study habits accumulate some level of anxiety or stress regarding upcoming exams, papers or presentations and this examination anxiety generally causes decrements in academic performance.

The results support the concept of anxiety and academic performance relationship as an interdependent system. Study indicates that the positive effects of achievement motivation was constant regardless of the situational manipulations. But sometimes situations facilitated performance in additive ways a concern had a differential effect on performance depends on levels of achievement motivation. Result also confirmed that educational aspirations of students may affect what they learn in school and their eventual success in academic. 
Motivation is assumed to have both energizing and directive effects on academic performance often may be attributed to anxiety.

\section{Limitations \& Suggestions}

The major limitation of the study is age range of the participants as all the data was drawn from higher secondary school and college students. Secondly, data was only collected from educated boys and girls. The results of the study could be more generalized by taking a broad based sample of earlier age range from school because the onset of social anxiety takes place in early adolescence.

\section{Implications}

The theoretical implication of this study rests in its contribution to two areas of psychology i.e., Education and Developmental psychology. And practical implication of this study seems to that it points out that aspiration significantly affects the achievement level of adolescents. This study can be helpful for children, parents and teachers to know that so anxiety is also hurdle in their academic achievements and success in life, so they must make effort to overcome it.

\section{References}

[1]. Alpert, R., Haber, R. N. (1960). Anxiety in academic achievement situations. The Journal of Abnormal and Social Psychology, 61(2), 207-215. doi:10.1037/h0045464

[2]. Anis-ul-Haque, M., Khan, S,. (1998). Age effect on academic, self-concept of high school children. Pakistan Journal of Psychological Research, 13(1-2), 35-42.

[3]. Ansari,Z.A.(1983). Study habits and attitude of students. Technical Report. National Institute of Psychology, Quaide-i-Azam University ,Islamabad.

[4]. Arbona,C.( 2000).Practice and Research in Career Counseling and Development. The Career Development Quarterly, 49( 2), 98134. doi: 10.1002/j.2161-0045.2000.tb00554.x

[5]. Areepattamannil, S., Freeman, J. G., \& Klinger, D. A. (2011). Influence of motivation, self-beliefs, and instructional practices on science achievement of adolescents in Canada. Social Psychology of Education, 14, 233-259. doi:10.1007/s11218-010-9144-9

[6]. Bendura, A., Barbaranelli, C., Caprara, G.V. \& Pastorelli, C. (1996). Multifaceted impact of self-efficacy beliefs on academic functioning. Journal of Child Development, 67(3), 1206-1222. doi: 10.1111/j.1467-8624.1996.tb01791

[7]. Bouffard, T., Marcoux, M., Vezeau, C., \& Bordeleau, L. (2003). Changes in self-perceptions of competence and intrinsic motivation among elementary school-children. British Journal of Educational Psychology, 73, 171-186. Retrieved from http://motordevelopment.tamu.edu/paper/is\%20perceived $\% 20$ motor $\% 20$ competence $\% 20 \mathrm{a} \% 20$ constraint $\% 20 \mathrm{in} \% 20 \mathrm{children's} \% 20 \mathrm{ac}$ tion\%20planning.pdf

[8]. Bouffard, T., Vezeau, C., \& Bordeleau, L. (1998). A development study of the relation between combined learning and performance goals and students' self-regulated learning. British Journal of Educational Psychology, 68, 309-318. Retrieved from www.aare.edu.au/05pap/bar05385.pdf

[9]. Campbell, M. M. (2007). Motivational systems theory and the academic performance of college students. Journal of College Teaching \& Learning, 4(7). Retrieved from http://www.cluteinstitute-onlinejournals.com/PDFs/353.pdf

[10]. Covington, M. (2004). Self worth goes to college: Or do our motivation theories motivate. In D.M. McInerney \& S. Van Etten (Eds.). Research on sociocultural influences on motivation andlearning Big theories revisited (pp. 91-114). Greenwich, CT: Information Age Press.

[11]. Covington, M. V. (2000). Goal theory, motivation, and school achievement: An integrative review. Annual Review of Psychology, 51(1), 171-190. doi: 10.1146/annurev.psych.51.1.171

[12]. Covington, M.V., Omelich, C.L., \& Schwarzer, R. (1986). Anxiety, aspirations, and self-concept in the achievement process: A longitudinal model with latent variables. Journal of Motivation and Emotion, 10(1), 71-88. doi;10.1007/BF00992151

[13]. Creasey, G., Jarvis, P., Knapcik, E.(2009).International Journal for the Scholarship of Teaching and Learning,3(2). Retrieved from http://www.georgiasouthern.edu/ijsotl

[14]. Culler, R. E., \& Holahan, C.J. (1980). Test anxiety and academic performance: The effects of study-related behaviors. Journal of Educational Psychology, 72(1), 16-20. doi: 10.1037/0022-0663.72.1.16

[15]. Deci, E. L., \& Ryan, R. M. (1985). Intrinsic motivation and self-determination in human behavior. New York: Plenum.

[16]. Diecidue, E., \& Van de Ven, J.(2008). Aspiration level, probability of success and failure, and expected utility. International Economic Review, 49, 683-700. doi:10.2139/ssrn.932019

[17]. Dweck, C.S. (2009). On learning to become a member of one's culture. In M. Tomasello, C. S. Dweck, J. Silk, B. Skryms, \& E.S. Spelke, Why We Cooperate. Boston, MA.: Boston Review. https://www.stanford.edu/dept/psychology/cgibin/drupalm/system/files/CV_1.pdf

[18]. Eccles, J. (2004). Schools, academic motivation, and stage-environment fit. In R. Lerner \&L. Steinberg (Eds.), Handbook of adolescent psychology (2ndEdition) (pp. 125-153). NewYork: Wiley.

[19]. Furlong, A., \& Cartmel, F. (2005). Graduates from Disadvantaged Families: Early Labour Market Experiences, Policy Press, Bristol.

[20]. Heafner, T. (2004). Using technology to motivate students to learn social studies. Contemporary Issues in Technology and Teacher Education [Online serial], 4(1). Retrieved from http://www.citejournal.org/vol4/iss1/socialstudies/article1.cfm

[21]. Heafner, T. L., \& McCoy, L. P. (2001). Technology and the academic and social culture of a university campus. In J. Price, D. Willis, N. Davis, \& J. Willis (Eds.), Proceedings of the Society for Information Technology in Teacher Education 01. Charlottesville, VA: Association for the Advancement of Computing in Education.

[22]. Hernedezs, A.(1994). Interpersonal relationship motivation engagement and achievement: yields for theory, current issues and educational practice. Review of Education, 79(1), 327-365. doi:10.3102/0034654308325583

[23]. Hornery, S., Craven, R.G., Yeung, A.S.,\& Ali, J.(2008). A New Multi-Dimensional Domain-Specific Motivation Questionnaire:Measurement of Young Children's Multi-faceted Reading Motivation. Paper presented at the Australian Association for Research in Education conference, Brisbane. 
[24]. Ismail, Z., \& Cochinwala, S. (1986). A study of the relationship of manifest anxiety with school achievement of $10^{\text {th }}$ grade students. Pakistan Journal of Psychology, 17(1-2),33-43. P-ISSN:0030-9869

[25]. Jayanti, O. (2008). The role of academic aspiration in shaping college academic performance (Paper presented at the annual meeting of American Sociological Association). http://www.allacademic.com $\backslash$ meta/p241569http://www.allacademic.com $\backslash$ meta/p241569_index.html

[26]. Jing, H. (2007). Analysis on the Relationship among Test Anxiety, Self-concept and Academic Competency. , 5(1), 48. Retrieved from http://www.linguist.org.cn/doc/uc200701/uc20070111.pdf

[27]. Kukla, A. (1974). Performance as a function of resultant achievement motivation (perceived ability) and perceived difficulty Journal of Research in Personality, 7(4), 374-383. doi:10.1016/0092-6566(74)90059

[28]. Kurita, J. A., \& Zarbatany, L. (1991). Teachers' acceptance of strategies for increasing students' achievement motivation.

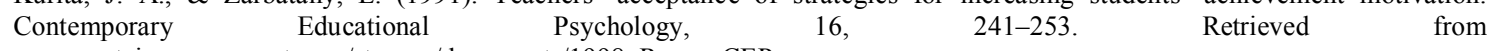
www.sustainengagement.com/storage/documents/1998_Reeve_CEP.

[29]. Marjoribanks, K. (1988). Ability and attitude correlates of aspirations: Personality-group differences. Journal of Experimental Education, 56. doi:10.1080/00223980209604157

[30]. McInerney, D. M., Roche, L. A., McInerney, V., \& Marsh, H. W. (1997). Cultural perspectives on school motivation: The relevance and application of goal theory. American Educational Research Journal, 34, 207-236. Retrieved from ink.springer.com/article/10.1007\%2Fs12187-011-9117-3

[31]. McInerney, D. M., Yeung, A. S., \& McInerney, V. (2001). Cross-cultural validation of the Inventory of School Motivation (ISM): Motivation orientations of Navajo and Anglo students. Journal of Applied Measurement, 2, 135-153. Retrieved from www.self.ox.ac.uk/Conferences/2006/Ali_2.pdf.

[32]. McKeachie, H., Wilbert, J., Karabenick, S. A., Guang, Y. L.(1998). The relationship between test anxiety and self-regulation on students' motivation and learning. Retrieved from $\mathrm{http}: / /$ www.google.com.pk/\#hl=en\&source=hp\&q=Bembenutty $\% 2 \mathrm{CHefer}+\% 2 \mathrm{Cs}+$ the + relationship + between + test + anxiety + andself + regulation+on+students+motivation+and+learning + find + doi\&aq $=$ o\&aqi $=\& a q l=\& o q=\& g s \_r f a i=\& f p=9$ ea39ed $30 \mathrm{~b} 15 \mathrm{e} 7 \mathrm{c} 5$

[33]. Miller, R.B. \& Brickman, S.J. (2004). A Model of Future-Orientated Motivation and Self-Regulation. Educational Psychology Review, 16(1), 9-33. Retrieved from ournals.ohiolink.edu/ejc/search.cgi?q=id:00220663/.../629...

[34]. Mohsen, R., \& Mansoor, T. (2009). Investigating the relationship among test anxiety, gender, academic achievement and years of study: A case of Iranian EFL university students. English Language Teaching, 2(4). Retrieved from http://www.ccsenet.org/journal/index.php/elt/article/view/4449

[35]. Mousavi, M., Haghshenas, H., \& Alishahi, M.J. (2008). Effect of gender, school performance and school type on test anxiety among Iranian adolescents. Iranian Red Crescent Medical Journal, 10, January, 4-7.

[36]. Nichols, T.M., Kotchick, B.A., Barry, C.M., \& Haskins, D.G. (2009). Understanding the educational aspiration of African Americans adolescents: child, family and community factors. Journal of Black Psychology, 36(1), 25-48. doi:10.1177/0095798409344084

[37]. Otello,D., \& Patricia,K. (1969). Anxiety, study habits, and academic achievement. Journal of Counseling Psychology,16(2, Pt.1),162-165. doi:10.1037/h0027213

[38]. Piedmont, R. (1988). The relationship between motivation, anxiety and situational characteristics on performance on a cognitive task. Journal of Research in Personality, 22(2), 177-187. doi:10.1016/0092-6566(88)90013

[39]. Pigatt, M. (2009). Analysis of high-academic achieving African American males. Focusing on success. Retrieved from http://www.sociology.emory.edu/SEUSS/archive/documents/FirstPlace2009.pdf

[40]. Pintrich, P. (2003). A motivational science perspective on the role of student motivation in learning and teaching contexts. Journal of Educational Psychology, 95, 667-686. doi: 10.1037/0022-0663.95.4.667. doi: 10.1037/0022-0663.95.4.667

[41]. Pintrich, P. R., \& DeGroot, E. V. (1990). Motivational and self-regulated learning components of classroom academic performance, Journal of Educational Psychology, 82,33-40.

[42]. Pintrich, P. R., Marx, R. W., \& Boyle, R. (1993). Beyond "cold" conceptual change: The role of motivational beliefs and classroom contextual factors in the process of conceptual change. Review of Educational Research, 63, 167-199.

[43]. Pintrich, P.R., \& Roeser, R.W. (1994). Classroom and individual differences in early predictive validity of the motivated strategies for learning questionnaire (MSLQ).Educational and Psychological Measurement, 53(2), 801-813. Retrieved from etd.lib.metu.edu.tr/upload/12614232/index.pdf

[44]. Quaglia, R. J., Cobb, C.D. (1996). Toward a Theory of Student Aspirations. Journal of Research in Rural Education,12 (3)127-132. Retrieved from php.scripts.psu.edu/dept/jrre/articles/v12,n3,p127-132,Quaglia.pdf

[45]. Ryan, R. M., Stiller, J., \& Lynch, J. H. (1994). Representations of relationships to teachers, parents, and friends as predictors of academic motivation and self-esteem. Journal of Early Adolescence,14, 226-249. Retrieved from http://www.eric.ed.gov/ERICWebPortal/search/detailmini.jsp?_nfpb=true\&_\&ERICExtSearch_SearchValue_0=EJ493539\&ERICE xtSearch_SearchType_0=no\&accno=EJ493539

[46]. Schunk, D. H. (1991). Self-efficacy and academic motivation. Educational Psychologist,26(3/4), 207-232. Retrieved from http://libres.uncg.edu/ir/uncg/f/d_schunk_self_1991.pdf

[47]. Seligman, M. E. P. (2002). Authentic Happiness: Using the New Positive Psychology to Realize Your Potential for Lasting Fulfillment. New York: Free Press. ISBN 0-7432-2297-0(Paperback edition, Free Press, 2004, ISBN 0-7432-2298-9)

[48]. Sharma \& Rao (1984).Test anxiety research in India: Twentieth century Retrospect. Psychology and Developing Societies,13,151 169.doi: $10.1177 / 097133360101300103$

[49]. Sideridis, G. D. (1998). Goal orientation, Academic achievement, and Depression evidence in Favor of Revised goal theory frame work. Journal of Educational Psychology, 93(3), 366-375. doi:10.1037/0022-0663-97-3-366

[50]. Smith, T.W., Snyder, C.R., \& Handelsman, M.M. (1982). On the self-serving function of an academic wooden leg: Test anxiety as a self handicapping strategy. Journal of Personality and Social Psychology, 42(2) 314-321. PMID: 7057356

[51]. Spielberger, C. D., \& Vagg, P. R. (1995). Test anxiety: A transactional process. In C. D. Spielberger \& P. Vagg (Eds.), Test anxiety: theory, assessment, and treatment (pp. 3-14). Washington, DC: Taylor \& Francis.

[52]. Stipek, D. J. (1997). Motivation and instruction. In David C. Berliner \& Rober C. Calfee (Eds.), Handbook of Educational Psychology (pp. 85-113). New York: MacMillan.

[53]. Taylor, J. A., \& Spence, K. W. (1954). Conditioning level in the behavior disorders. The Journal of Abnormal and Social Psychology, 49(4), 497-502. doi: 10.1037/h0055951

[54]. Tsang, W. K. (1992). The class structure in Hong Kong. Hong Kong: Hong Kong Institute of Asia-Pacific Studies, Chinese University of Hong Kong. 
[55]. Urhahne, D., Chao, S.H., Florineth, M.L., Luttenberger, S., \& Paechter, M.(2011). Academic self-concept, learning, motivation and test anxiety of the underestimated students. British Journal of Educational Psychology, 81(1), 161-177. doi; $1348 / 000709910 \times 504500$

[56]. Vesta, F. J. D. (1961). Meaningful learning, personality, interpersonal, and social variables. American Educational Research Association, 31(5), 511-521. doi:10.3102\00346543031005511

[57]. Vogel, H. L., Collins, A. L. (1989). The relationship between test anxiety and academic performance. Retrieved from http://clearinghouse.missourwestern.edu/manuscripts/333.php

[58]. Yeunga, A. S., \& McInerney, D.M.(2005). Educational Psychology. An International Journal of Experimental Educational Psychology, 25(5), 537-554.doi:10.1080/01443410500046804

[59]. Yousefi, F., Abutalib, M., Mansoor, M.B., \& Juhari, R.B. (2010). Relationship between test anxiety and academic achievement among Iranian adolescents .Journal of Asian Social Science. Retrieved from http://www.ccsentet.org/journal/index.php/ass/article/view/5979

[60]. Zeidner, M. (1998). Test anxiety: The state of the art. New York: Plenum.

[61]. Zimmerman, B.J. (1990). Self-regulated learning and academic achievement. An Overview Educational Psychology, $25(1)$, 3-17. doi: $10.1207 / \mathrm{s} 15326985 \mathrm{ep} 2501$ 